\title{
CHARACTERIZATION OF THE CHOLINERGIC STIMULATION OF PHOSPHOINOSITIDE HYDROLYSIS IN RAT BRAIN SLICES ${ }^{1}$
}

\author{
RUEBEN A. GONZALES AND FULTON T. CREWS ${ }^{2}$ \\ Department of Pharmacology, The University of Florida Medical School, J. Hillis Miller Health Center, Gainesuille, Florida 32610
}

Received March 14, 1984; Revised May 14, 1984; Accepted May 16, 1984

\begin{abstract}
The stimulation of the formation of inositol phosphates by various cholinergic agonists and antagonists was studied in rat brain cortical slices. Incubation of the slices with $\left[{ }^{3} \mathrm{H}\right]$ inositol led to the incorporation of radioactivity into inositol lipids. The accumulation of inositol phosphates was then followed in the presence of $8 \mathrm{~mm}$ lithium which blocks the hydrolysis of inositol phosphate. The release of inositol phosphate was linear up to $15 \mathrm{~min}$ when stimulated by $1 \mathrm{~mm}$ carbachol. Acetylcholine, muscarine, and methacholine also stimulated the release of inositol phosphates with about the same efficacy as carbachol. Oxotremorine, arecoline, pilocarpine, and bethanechol were not as effective as carbachol at stimulating the accumulation of inositol phosphates. Indicative of partial agonist activity, oxotremorine and pilocarpine inhibited the maximal response induced by carbachol. Muscarinic antagonists atropine, scopolamine, and pirenzepine blocked the stimulation by acetylcholine in contrast to nicotinic antagonists, which had no effect. The brain regional response to carbachol-stimulated inositol phosphate release varied widely with large responses observed in the striatum, cerebral cortex, and hippocampus. Smaller responses were seen in the brainstem, hypothalamus, and cerebellum. Although carbachol stimulated inositol phosphate release in cortical slices in the absence of added calcium, EGTA completely blocked the response. These results suggest that the previously characterized stimulation of the incorporation of ${ }^{32} \mathrm{P}_{\mathrm{i}}$ into phosphatidylinositol by cholinergic agonists in synaptosomes (Fisher, $\mathrm{S}$. K., $\mathrm{P}$. D. Klinger, and B. W. Agranoff (1983) J. Biol. Chem. 258: 7358-7363) is due to the initial hydrolysis of inositol lipids. This response may be coupled to the M1 subtype of muscarinic receptor and may represent the initial step in an intraneuronal cascade involving the activation of phospholipid-calcium-dependent protein kinase by the liberated diacylglycerol.
\end{abstract}

Acetylcholine is one of the major neurotransmitters in brain. The muscarinic cholinergic cascade in brain and other tissues appears to involve the hydrolysis of phosphoinositides to form diacylglycerol and inositol phosphates which can serve as second messengers (Berridge et al., 1983; Michell, 1983). Although muscarinic cholinergic stimulation can increase $\left[{ }^{32} \mathrm{P}\right]$ orthophosphate incorporation into phosphatidylinositol (PI) (Fisher et al., 1983), the synthesis and breakdown of PI are not always linked (Farese, 1983). Recent studies have indicated that lithium prevents the dephosphorylation of inositol phosphate (Sherman et al., 1981). By incubating brain slices in the presence of lithium, the breakdown of PI can be directly followed by measuring the accumulation of inositol phosphate (Berridge et al., 1982). Therefore, we have developed a method to measure inositol phosphate in brain slices and have characterized the effects of various cholinergic agonists and antagonists on the accumulation of inositol phosphate in rat brain.

We report here that acetylcholine and other cholinergic agonists cause a marked increase in inositol phosphate accumulation. Cholinergic stimulation is blocked by atropine, sug-

\footnotetext{
${ }^{1}$ This work was supported by American Federation for Aging Research Grant AFAR 1576 and by National Institute of Alcohol Abuse and Alcoholism Grant AA06069. We wish to thank Dr. P. Downes for his helpful comments.

${ }^{2}$ To whom correspondence should be addressed.
}

gesting a muscarinic receptor. Certain muscarinic agents such as oxotremorine appear to be partial agonists at this receptor. There is a regional distribution to this response, with the cerebral cortex, hippocampus, and striatum exhibiting the greatest responses. The cholinergic stimulation of inositide breakdown probably represents the initial step in a cascade which leads to the activation of protein kinases which alter membrane conductances and nerve firing.

\section{Materials and Methods}

All drugs used in this study were purchased from Sigma Chemical Co. with the exception of pirenzepine, which was kindly donated by $L$. Potter, University of Miami. Solvents were analytical grade from Fisher Scientific Co.

Brain slice preparation. Male Sprague-Dawley rats (200 to $300 \mathrm{gm}$ ) were obtained from the colony maintained at the University of Florida (Gainesville, FL). Rats were decapitated, and brains were rapidly removed and bathed in warm Krebs-Ringer bicarbonate buffer (KRB) $\left(118 \mathrm{mM} \mathrm{NaCl} 4.7 \mathrm{mM} \mathrm{KCl}, 0.75 \mathrm{mM} \mathrm{CaCl}_{2}, 1.18 \mathrm{mM} \mathrm{KH}_{2} \mathrm{PO}_{4}, 1.18\right.$ $\mathrm{mM} \mathrm{MgSO}_{4}, 24.8 \mathrm{mM} \mathrm{NaHCO}_{3}, 10 \mathrm{mM}$ glucose) which had been bubbled with $\mathrm{O}_{2} / \mathrm{CO}_{2}$ (95:5). In most experiments, slices of cerebral cortex were made parallel to the surface, taking care to exclude white matter. Slices from two rat cortices were pooled and then further sliced using a McIlwain tissue chopper to a thickness of $350 \mu \mathrm{m}$ in two perpendicular directions. The minced tissue was rapidly transferred to a flask containing $\mathrm{KRB}$ at $37^{\circ} \mathrm{C}$ and dispersed. The tissue was continually agitated gently while being bubbled with $\mathrm{O}_{2} / \mathrm{CO}_{2}$. After the slices had been dispersed, they were washed four times in $30 \mathrm{~min}$ with fresh KRB. 
Washing was performed by allowing the slices to settle, removing the buffer with a pipette, and rapidly replacing it with fresh oxygenated KRB.

Dissection of brain regions. Brains were dissected as follows. The brain was rapidly removed and placed upright on a dissection platform wetted with warm KRB. The olfactory bulbs were removed at the stalk, cut in half longitudinally, and placed on the tissue chopper disc for slicing. The cortices were dissected using a razor blade to cut slices 1 to $2 \mathrm{~mm}$ in thickness, avoiding underlying white matter. For this report, frontal cortex refers to slices made from the upper surface of the brain between the frontal pole and rostral to the optic chiasm. Parietal cortex is caudal to the optic chiasm occupying the upper and lateral cortex corresponding to anterior and posterior cingulate cortex (Paxinos and Watson, 1982). Occipital cortex is defined as being above and behind the posterior portion of the rat hippocampus and folding over the colliculi, i.e., the striatal and retrosplenial cortex (see Paxinos and Watson, 1982). After the cortical slices were removed, the remaining cortex and corpus callosum were peeled back to reveal the intact hippocampus. The septal hippocampal connections were cut and both hippocampi were removed intact. The brain was then rotated such that the inferior surface was up. A frontal section cut was made at the optic chiasm. The striatum was dissected from the frontal piece by trimming away the surrounding regions. The striatum was sliced with a razor blade into slices 1 to $2 \mathrm{~mm}$ thick and then further sliced using the McIlwain tissue chopper as described above. The cerebellum was removed by severing the peduncles, sliced into sheets by hand, and then further sliced with the tissue chopper. The brainstem was prepared in a similar way. The hypothalamus was dissected by making frontal section cuts at the optic chiasm and just caudual to the mammillary bodies. Sagittal cuts were made approximately $2 \mathrm{~mm}$ lateral to the central plane. A coronal cut was then made through the anterior commissure to denote the upper surface of the hypothalamus.

Incubation with $\left[{ }^{3} H\right]$ inositol. Following the wash period, the slices were allowed to settle, excess buffer was aspirated, and the volume of packed slices was estimated (usually $1.5 \mathrm{ml} /$ cortex). The slices were transferred to a $50-\mathrm{ml}$ conical tube and then diluted with $4 \mathrm{vol}$ of KRB to which had been added $\left[{ }^{3} \mathrm{H}\right]$ inositol $(15.5$ or $16.4 \mathrm{Ci} / \mathrm{mmol}$; Amersham Corp.) to give a final concentration of 0.1 to $0.3 \mu \mathrm{M}$. The tube was gassed with $\mathrm{O}_{2} / \mathrm{CO}_{2}$, capped tightly, and then incubated for 1 -hr at $37^{\circ} \mathrm{C}$ in a shaking water bath. Care was taken to agitate the slices enough to prevent settling during this incubation. Placing the tube at an angle facilitated this process. To measure the amount of label incorporated into lipids, $0.2 \mathrm{ml}$ of the slices was added to $0.8 \mathrm{ml}$ of icecold water to stop the incorporation. The slices were then homogenized with a Tekmar SDT for $15 \mathrm{sec}$ at a medium setting. Aliquots were then taken for determination of protein by the method of Lowry et al. (1951) and for lipid extraction as described below.

Slices used for $\left[{ }^{3} \mathrm{H}\right]$ inositol phosphate release were allowed to settle and the medium was removed. The slices were washed twice with fresh $\mathrm{KRB}$ and then made up to a volume 3 to 4 times the initial incubated volume of packed slices. This volume is critical to maintain the protein concentration below $600 \mu \mathrm{g}$ in a $50-\mu \mathrm{l}$ aliquot. While gently agitating the slices, $50 \mu \mathrm{l}$ were transferred to a Falcon 2063 polypropylene tube $(12 \times 75 \mathrm{~mm})$ containing $190 \mu \mathrm{l}$ of KRB with $10 \mathrm{mM} \mathrm{LiCl} \mathrm{substituted}$ isotonically for $\mathrm{NaCl}\left(8 \mathrm{~mm}\right.$ final $\mathrm{Li}^{+}$concentration). 'T'o start the reaction, $10 \mu \mathrm{l}$ of an appropriate agonist or buffer were added. The tube was gassed with $\mathrm{O}_{2} / \mathrm{CO}_{2}$, capped tightly, and shaken in an incubator at $37^{\circ} \mathrm{C}$. The reaction was stopped by adding $1.0 \mathrm{ml}$ of chloroform:methanol $(1: 2, \mathrm{v} / \mathrm{v})$.

Lipid extraction and separation. To tubes containing $0.25-\mathrm{ml}$ slices, either homogenized or intact, $1.0 \mathrm{ml}$ of chloroform:methanol $(1: 2, \mathrm{v} / \mathrm{v})$ was added. An additional $0.35 \mathrm{ml}$ of distilled water and $0.35 \mathrm{ml}$ of chloroform was added, and the tubes were capped tightly and shaken for $10 \mathrm{~min}$. The tubes were then briefly centrifuged at low speed to separate the phases and $0.75 \mathrm{ml}$ of the upper aqueous phase was taken for Dowex chromatography. The remaining upper phase and interface were aspirated, and $200 \mu \mathrm{l}$ of the chloroform layer were taken for determination of radioactivity incorporated into membrane lipids. Five milliliters of OCS scintillation fluid (Amersham) were used as the scintillant, and radioactivity was determined using a Beckman LS7500 liquid scintillation counter.

For thin layer chromatography (TLC), the chloroform was evaporated to dryness and the residue was taken up in a small volume of fresh chloroform (usually $100 \mu \mathrm{l}$ ). This was then spotted at the origin of a Silica Gel G thin layer plate (Redi-Coat-2D, $0.25 \mathrm{~mm}$ from Supelco,
Inc.). Authentic phospholipid standards were also spotted (Avanti Polar Lipids). For one-dimensional chromatography, the solvent system was chloroform:methanol:ammonium hydroxide:water $(70: 30: 2: 3$, by volume). For two-dimensional chromatography, the second solvent system was chloroform-methanol:acetone:acetic acid:water (30:10:40:10:5, by volume) according to the method of Rouser et al. (1969). PI was completely separated from the other major phospholipids under these conditions.

Separation of water-soluble products. Labeled inositol phosphates were analyzed following the methods of Berridge et al. (1982) and Berridge (1983). For analysis of inositol phosphate derived from the receptor-stimulated breakdown of phosphoinositides, a sample of the aqueous phase was diluted to $3 \mathrm{ml}$ with water. One milliliter of a slurry of Dowex-1 $(50 \%, v / v ; X 8 ; 100$ to 200 mesh from Sigma) in the formate form was added. The slurry containing the bound inositol phosphates was then poured into a polypropylene column with a fritted disk. After allowing the liquid to drain, the resin was washed four times with 2.5 $\mathrm{ml}$ of $5 \mathrm{~mm}$ myo-inositol. Total inositol phosphates were eluted with five $1-\mathrm{ml}$ washes with $0.1 \mathrm{M}$ formic acid/1.0 $\mathrm{M}$ ammonium formate directly into a vial. Ten milliliters of Liquiscint (National Diagnostics) were added prior to determination of radioactivity as described above. To separate the individual inositol phosphates, the technique of Berridge et al. (1983) was used. Five 1-ml aliquots of each of the following solutions were added to the Dowex column: $5 \mathrm{~mm}$ disodium tetraborate/ $60 \mathrm{~mm}$ sodium formate; $0.1 \mathrm{M}$ formic acid/ $0.2 \mathrm{M}$ ammonium formate; $0.1 \mathrm{M}$ formic acid/0.4 M ammonium formate; $0.1 \mathrm{M}$ formic acid/1.0 M ammonium formate. These solutions elute sequentially glycerophos phoinositol, inositol 1-phosphate, inositol 1,4-diphosphate, and inositol 1,4,5-triphosphate.

Analysis of polyphosphoinosilides by lipid deacylation and Dowex chromatography. Slices of cortex $(0.2 \mathrm{ml}$ of packed tissue) which had been incubated with $\left[{ }^{3} \mathrm{H}\right]$ inositol for $1 \mathrm{hr}$ were extracted as described above except that $0.35 \mathrm{ml}$ of $1 \mathrm{~N} \mathrm{HCl}$ was added to the slices instead of water to ensure complete extraction of these acidic lipids (Downes and Michell, 1982). The upper phase was removed and the lower phase was evaporated to dryness. Using the method of Clarke and Dawson (1981), the residue was taken up in $0.75 \mathrm{ml}$ of methylamine reagent (methylamine:methanol:water:butanol; 5:4:3:1) and incubated for $60 \mathrm{~min}$ at $53^{\circ} \mathrm{C}$. The reagent was subsequently removed by evaporation and the residue was resuspended in $1 \mathrm{ml}$ of water. This mixture was extracted with $1.2 \mathrm{ml}$ of $n$-butanol:petroleum ether:ethyl formate (20:4:1). After removing the upper phase, the lower phase was washed again with 0.75 $\mathrm{ml}$ of the same solvent. An aliquot $(0.70 \mathrm{ml})$ of the lower phase containing the water-soluble products from deacylation of phospholipids was then diluted to $3 \mathrm{ml}$ with water prior to chromatography on a Dowex-1 column as previously described. The eluting solvents were 10 $\mathrm{ml}$ each of: water, $5 \mathrm{~mm}$ sodium tetraborate $/ 0.18 \mathrm{~mm}$ ammonium formate, $0.3 \mathrm{M}$ ammonium formate $/ 0.1 \mathrm{M}$ formic acid, $0.75 \mathrm{M}$ ammonium formate $/ 0.1 \mathrm{M}$ formic acid. These solvents remove free inositol, glycerophosphoinositol, glycerophosphoinositol 4-phosphate, and glycerophosphoinositol 4,5-diphosphate, respectively (Berridge, 1983).

Statistical analysis. Significant differences between control and experimental groups were determined by analysis of variance using the Newman-Keuls method as the post hoc test. Differences were considered significant if $p<0.05$ was achieved. $\mathrm{ED}_{50}$ values for concentrationeffect curves were determined using probit analysis as outlined by Goldstein (1964).

\section{Results}

Incorporation of $\left[{ }^{3} \mathrm{H}\right]$ inositol into phospholipids. To characterize the incorporation of $\left[{ }^{3} \mathrm{H}\right]$ inositol into phospholipids, cerebral cortical slices were incubated for various times with $\left[{ }^{3} \mathrm{H}\right]$ inositol, and the lipids were extracted. For the first $15 \mathrm{~min}$, there was a slow linear incorporation of $\left[{ }^{3} \mathrm{H}\right]$ inositol into lipids which increased in rate after $15 \mathrm{~min}$ (Fig. 1, inset). This rate was linear for approximately $60 \mathrm{~min}$, when it began to slow. Incorporation reached a maximum at about $240 \mathrm{~min}$.

To determine into which lipids $\left[{ }^{3} \mathrm{H}\right]$ inositol was incorporated, we extracted and separated the various lipid components of the membrane. Analysis by one-dimensional TLC indicated that $88.5 \%$ of the radioactivity recovered co-migrated with PI. A small proportion of the radioactivity remained at the origin $(11 \%)$, suggesting the presence of labeled polyphosphoinositides. Two-dimensional TLC confirmed that the major radio- 
Figure 1. Effect of $\left[{ }^{3} \mathrm{H}\right]$ inositol concentration on $\left[{ }^{3} \mathrm{H}\right]$ inositol incorporation into brain slice lipid. Slices were preparcd and incubated as described under "Materials $(15.5 \mathrm{Ci} / \mathrm{mmol})$. After $1 \mathrm{hr}$, uptake was stopped by addition of $1 \mathrm{ml}$ of chloroform:methanol $(1: 2, \mathrm{v} / \mathrm{v})$. The lipids were extracted, and an aliquot of the chloroform layer was counted. The average protein content per tube was $690 \mu \mathrm{g}$. Data are presented as the mean $\pm \mathrm{SEM}$ of triplicate determinations of a single preparation. and Methods" with various concentrations of $\left[{ }^{3} \mathrm{H}\right]$ inositol
Figure 2. Time course of $\left[{ }^{3} \mathrm{H}\right]$ inositol incorporation into cortical slices. Slices were prepared and incubated with $0.11 \mu \mathrm{M}\left[{ }^{3} \mathrm{H}\right]$ inositol $(16.4 \mathrm{Ci} / \mathrm{mmol}$ ) (see "Materials and Methods"). At the appropriate times, $0.2-\mathrm{ml}$ aliquots were removed and placed in $0.8 \mathrm{ml}$ of ice-cold water. Samples were homogenized and the protein content and radioactivity incorporated into lipids were determined. Data are presented as the mean \pm SEM of triplicate determinations on a single preparation. Similar results were obtained in two separate experiments.
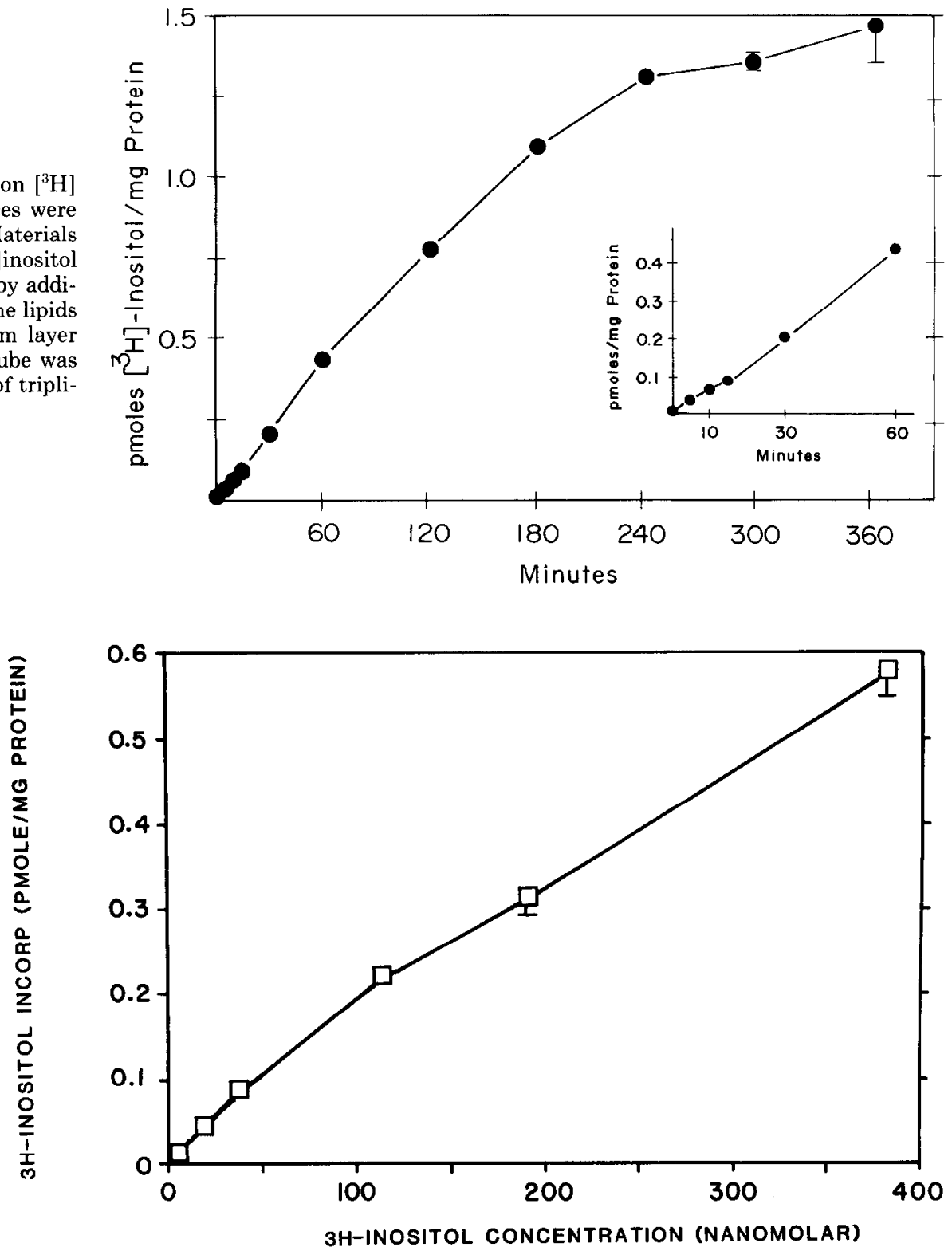

active peak was associated with PI and not the other major lipid components of the membranes. To further identify the lipids which were labeled, lipid extracts were deacylated and the water-soluble products were separated by anion exchange chromatography. The label was incorporated into three fractions corresponding to hydrolysis products of PI, phosphatidylinositol 4-phosphate, and phosphatidylinositol 4,5-bisphosphate in a ratio of $85: 10: 5$.

To characterize further the incorporation of $\left[{ }^{3} \mathrm{H}\right]$ inositol into brain slices, we studied the effect of $\left[{ }^{3} \mathrm{H}\right]$ inositol concentration. Incorporation was linear up to approximately $100 \mathrm{nM}$ and then began to fall off (Fig. 2). Our studies of the breakdown of inositides were done using a prelabeling concentration of $\left[{ }^{3} \mathrm{H}\right]$ inositol in the range of 100 to $200 \mathrm{nM}$. The incorporation studies described here indicate that $\left[{ }^{3} \mathrm{H}\right]$ inositol is specifically incorporated into inositol lipids in rat cerebral cortical slices.

Release of $\left[{ }^{3} H\right]$ inositol phosphates. To investigate the ability of cholinergic agonists to stimulate the breakdown of inositol lipids, cortical slices were labeled for $60 \mathrm{~min}$ with $\left[{ }^{3} \mathrm{H}\right]$ inositol, washed, and then stimulated with various drugs in the presence of lithium. We chose carbachol as our prototypical agonist. Slices incubated with carbachol for $60 \mathrm{~min}$ had an increase in radioactivity recovered in aqueous extracts. To determine the relative contribution of individual inositol phosphates to the increase in radioactivity, phosphate esters bound to a Dowex column were eluted by the stepwise addition of various formate solutions which separate inositol 1-phosphate, inositol 1,4diphosphate, and inositol 1,4,5-triphosphate (see "Materials and Methods" and Berridge et al., 1983). A single peak was obtained which was eluted with $0.1 \mathrm{M}$ formic acid/0.2 $\mathrm{M}$ ammonium formate, suggesting that only inositol 1-phosphate was increased. To confirm that this peak co-eluted with inositol 1phosphate, we synthesized $\left[{ }^{3} \mathrm{H}\right]$ inositol 1-phosphate by purifying labeled PI by TLC and hydrolyzing it with phospholipase C (bacillus cereus, Sigma). The standard inositol 1-phosphate we prepared was eluted at the same concentration of formate as that found released from stimulated cortical slices. Thus, as in other peripheral tissues, the stimulation of inositide hydrolysis in the presence of lithium results in the accumulation of inositol phosphate in rat brain cortex (Berridge et al., 1982; Brown and Brown, 1983).

Preliminary experiments were done to determine the relationship between protein concentration and the stimulation of hydrolysis of inositides by carbachol. These studies indicated that it was difficult to distribute slices such that each tube contained the same amount of protein. Careful attention to the 


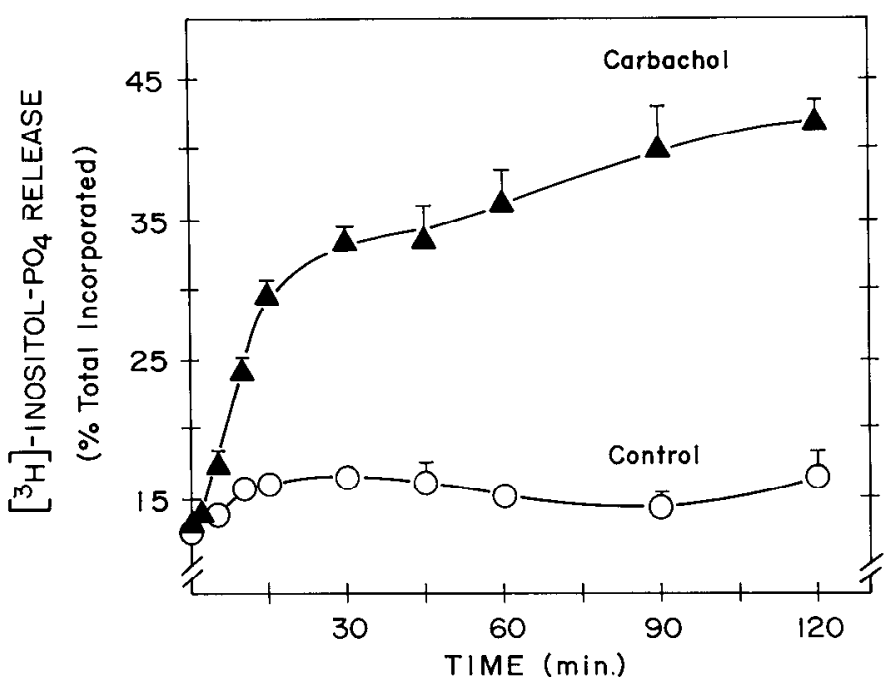

Figure 3. Time course of $\left[{ }^{3} \mathrm{H}\right]$ inositol phosphate release. Slices were labeled for $1 \mathrm{hr}$ with $0.27 \mu \mathrm{M}\left[{ }^{3} \mathrm{H}\right]$ inositol $(16.4 \mathrm{Ci} / \mathrm{mmol})$. After washing and dilution of the slices, $50-\mu \mathrm{l}$ aliquots of the dispersed slices were transferred to tubes containing KRB with lithium. Ten microliters of buffer with or without carbachol ( $1 \mathrm{~mm}$ final concentration) were added and the tubes were gassed with $\mathrm{O}_{2} / \mathrm{CO}_{2}$ (95:5), capped, and incubated for various times. Reactions were terminated by the addition of $1.0 \mathrm{ml}$ of chloroformmethanol $(1: 2, \mathrm{v} / \mathrm{v})$. Lipids were extracted and the amount of label in inositol phosphates was determined by Dowex-1 chromatography (see "Materials and Methods"). Results from a single preparation are shown as the mean \pm SEM of triplicate incubations and are expressed as the ratio of the amount of label in $\left[{ }^{3} \mathrm{H}\right]$ inositol phosphate to the total label incorporated into lipids.

\section{TABLE I}

Potencies and efficacies of a series of cholinergic agonists on the breakdown of inositides in cortical slices

Slices were labeled with $\left[{ }^{3} \mathrm{H}\right]$ inositol and incubated in triplicate with various concentrations of the indicated drugs for $60 \mathrm{~min}$ as described under "Materials and Methods." Drug concentrations usually ranged from 1 to $3000 \mu \mathrm{M}$. $\mathrm{ED}_{\bar{\kappa}}$ was determined by probit analysis. Where $N$ $>1$ the mean \pm SEM or range is shown. Carbachol $(1 \mathrm{mM})$ was included in every experiment as a positive control. Eserine $(10 \mu \mathrm{M})$ was included in the experiments with acetylcholine.

\begin{tabular}{lccc}
\hline \multicolumn{1}{c}{$\Lambda$ gonist } & $\mathrm{ED}_{5 \mathrm{v}}(\mu \mathrm{M})$ & $\begin{array}{c}\text { Maximum Response } \\
\text { (Fraction of Maximal } \\
\text { Carbachol Response) }\end{array}$ & $N$ \\
\hline Carbachol & $47 \pm 9$ & 1.0 & 3 \\
Acetylcholine & $36 \pm 12$ & $1.40 \pm 0.2$ & 3 \\
Methacholine & 205 & 0.96 & 1 \\
Muscarine & 33 & 0.84 & 1 \\
Oxotremorine & 25 & $0.23 \pm 0.1$ & 2 \\
Arecoline & $66 \pm 18$ & $0.42 \pm 0.05$ & 2 \\
Pilocarpine & 15 & 0.32 & 1 \\
Bethanechol & 53 & 0.59 & 1 \\
\hline
\end{tabular}

protein concentration revealed that nonstimulated release was linear over a broad range of protein concentrations. The ability of carbachol to stimulate the release of inositol phosphate increased linearly with protein concentration up to approximately $600 \mu \mathrm{g} /$ tube and then began to plateau. Variations in the release of inositol phosphate due to variations in the amount of slices per aliquot are less at higher protein concentrations since the flattening of the protein curve reduces variations in responses due to different amounts of protein. We thought it was important to do our studies on the linear portion of the protein curve, i.e., below $600 \mu \mathrm{g}$ of protein/tube, where the carbachol response was maximal.

To account for variations in the amount of slices per tube at low protein concentrations, we have expressed our data as $\left[{ }^{3} \mathrm{H}\right]$ inositol phosphate released per total $\left[{ }^{3} \mathrm{H}\right]$ inositol incorporated into lipid for each tube (dissociations per minute (DPM) recovered from column/(DPM from column + DPM in lipid) $\times$ $100)$. When the protein curve data are expressed in this way, a reduction in carbachol response is observed at protein concentrations above $600 \mu \mathrm{g} /$ tube.

To determine the time course of $\left[{ }^{3} \mathrm{H}\right]$ inositol phosphate release, slices were incubated with carbachol for various times. Although there was a hint of stimulated release at $1 \mathrm{~min}$, there was a significant increase in release at $5 \mathrm{~min}$ which continued linearly for about $15 \mathrm{~min}$ (Fig. 3). Stimulated release continued to increase at a much slower rate beyond $15 \mathrm{~min}$ reaching a maximum of approximately $40 \%$ between 60 and $90 \mathrm{~min}$. Nonstimulated release was approximately 12 to $17 \%$ throughout the time period studied.

Effects of cholinergic agonists. Complete dose response curves to a series of cholinergic agonists were performed. Marked differences in efficacy and potency were found. Acetylcholine, carbachol, methacholine, and muscarine were found to be the most effective agonists (Table I, Fig. 4). Bethanechol had intermediate activity, and arecoline, pilocarpine, and oxotremorine were relatively weak agonists. These results indicate that there are striking differences in the ability of various cholinergic agonists to stimulate inositol lipid breakdown which are not related to their potency (Table I).

To characterize the apparent partial agonist activity of oxotremorine, a concentration-effect curve was done in the presence and absence of a maximally stimulating concentration of carbachol. Indicative of a partial agonist, oxotremorine caused an increase in the release of inositol phosphate by itself while decreasing the ability of carbachol to stimulate release down to the maximum induced by oxotremorine alone (Fig. 5). Similar results were obtained with pilocarpine. These results suggest that oxotremorine, pilocarpine, arecoline, and bethanechol are partial agonists at this cholinergic receptor.

The properties of the cholinergic receptor responsible for mediating inositol lipid breakdown were investigated by using various cholinergic antagonists. Scopolamine and atropine (1 $\mu \mathrm{M})$ completely blocked the release of inositol phosphate induced by $100 \mu \mathrm{M}$ acetylcholine (Fig. 6). Gallamine, hexamethonium, and $d$-tubocurarine had no effect on acetylcholine-stimulated inositol phosphate release at a concentration of $1 \mu \mathrm{M}$ (Fig. 6). In addition, pirenzepine, a selective $M_{1}$ antagonist, blocked the carbachol $(100 \mu \mathrm{M})$-stimulated release of inositol phosphate with an $\mathrm{ED}_{50}$ of approximately $0.1 \mu \mathrm{M}$ (Fig. 7). None of the antagonists had any effect on nonstimulated release at this concentration. In addition, the nicotinic receptor agonist 1,1-dimethyl-4-phenylpiperazinium iodide had no effect on the release of inositol phosphate at concentrations up to $1 \mathrm{mM}$. These results indicate that the cholinergic receptor which mediates inositide breakdown in brain slices is muscarinic.

Brain regional characterization of carbachol-stimulated inositide breakdown. Nine separate brain regions were analyzed for their ability to form inositol phosphate in the presence and absence of a maximally stimulating concentration of carbachol. There were large differences in the regional response to carbachol (Fig. 8). Striatum, cerebral cortex, hippocampus, and olfactory bulb showed the largest responses. Frontal, parietal, and occipital cortex showed approximately equal responses. The cerebellum had the lowest stimulated inositol phosphate release, and the brainstem and hypothalamus were intermediate in responsiveness.

Calcium dependence of carbachol-stimulated inositide breakdown. Many studies have suggested that the increased metabolism of PI induced by a variety of agents may be involved in the control of calcium gating (Michell, 1975). If this were true in brain slices, one would expect that the response produced by 
Figure 4. Concentration-effect curves for cholinergic agonists for the stimulation of inositide breakdown. The release of $\left[{ }^{3} \mathrm{H}\right]$ inositol phosphate after $60 \mathrm{~min}$ in the presence of agonists was determined as described under "Materials and Methods." The amount of radioactivity found in the inositol phosphate fraction at time zero was taken as the blank and subtracted from both nonstimulated and stimulated values. To determine the curve for acetylcholine, $10 \mu \mathrm{M}$ eserine was added. Data are a compilation of five separate experiments (means \pm SEM of triplicates). Carbachol (1 mM) was used as a positive control (shown on the right as the single open circle) in all experiments. $A C h$, acetylcholine; Carb, carbachol; Arec, arecoline; Oxo, oxotremorine; Meth, methacholine; Musc, muscarine; Beth, bethanechol; Pilo, pilocarpine.

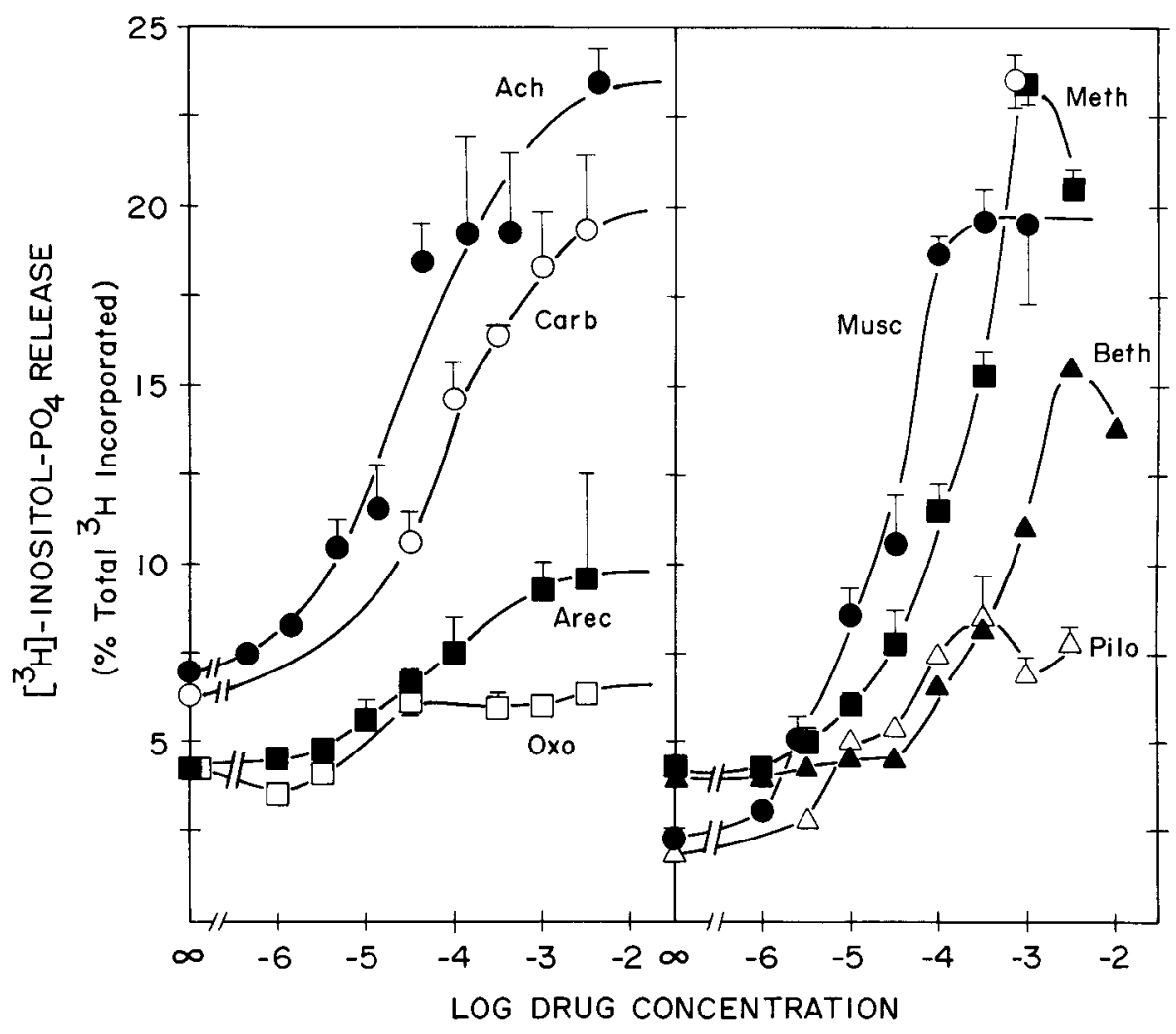

Figure 5. Partial agonist activity of oxotremorine. Data were derived as described in the legend to Figure 4. Shown are the mean \pm SEM of triplicate determinations on a single preparation.

carbachol would be independent of the extracellular calcium concentration. We have investigated the calcium dependence of carbachol-stimulated inositide breakdown using the present method. Removal of calcium from the incubation medium still allowed a robust response in the presence of carbachol. However, addition of calcium to concentrations as low as $0.1 \mathrm{M}$ caused a significant increase in this response (Fig. 9). Addition of calcium seemed to increase basal release slightly, but this effect did not reach statistical significance (analysis of variance, $p>0.05)$. When EGTA $(200 \mu \mathrm{M})$ was added to the buffer, no significant stimulation of inositol lipid breakdown was observed.

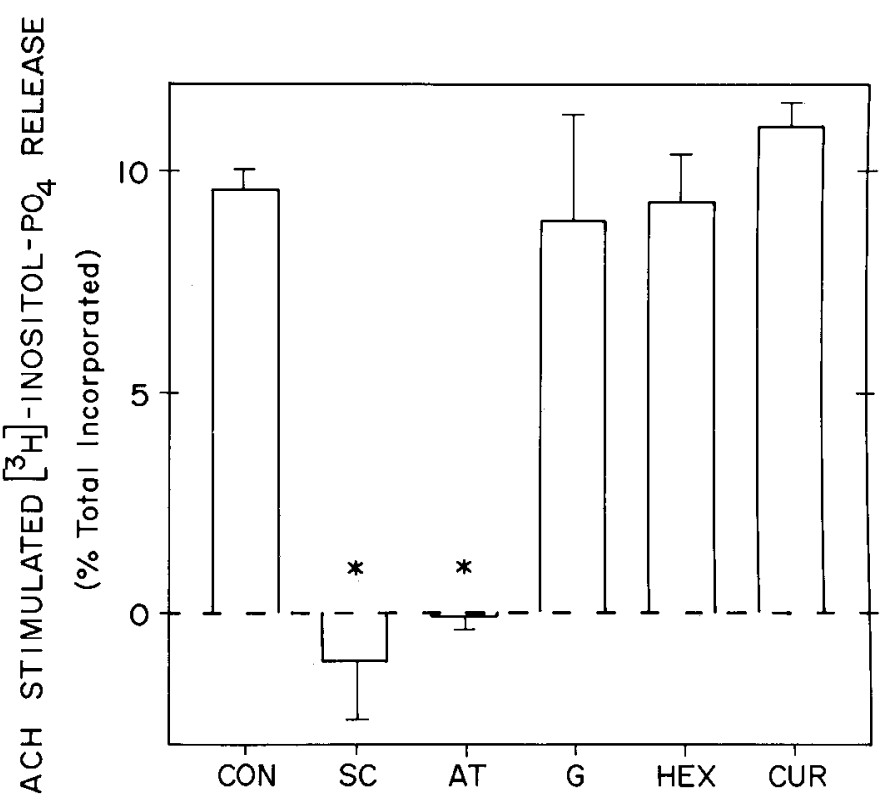

Figure 6. Effects of cholinergic antagonists on acetylcholine-stimulated inositide breakdown. Data were obtained as described in the legend to Figure 4 . Slices were incubated in the presence of $1 \mu \mathrm{M}$ of the antagonists and $10 \mu \mathrm{M}$ eserine $10 \mathrm{~min}$ before addition of acetylcholine (100 $\mu \mathrm{M}$ final concentration). Results are presented as the mean \pm SEM of triplicates for a single slice preparation. Similar results were obtained with atropine in two separate experiments. Asterisks indicate significant difference from control (analysis of variance, followed by Newman-Keuls test, $p<0.05$ ).

\section{Discussion}

Cholinergic neurotransmission in rat brain occurs predominantly through stimulation of muscarinic receptors (Krnjevic, 1974). A typical response to muscarinic receptor activation in 


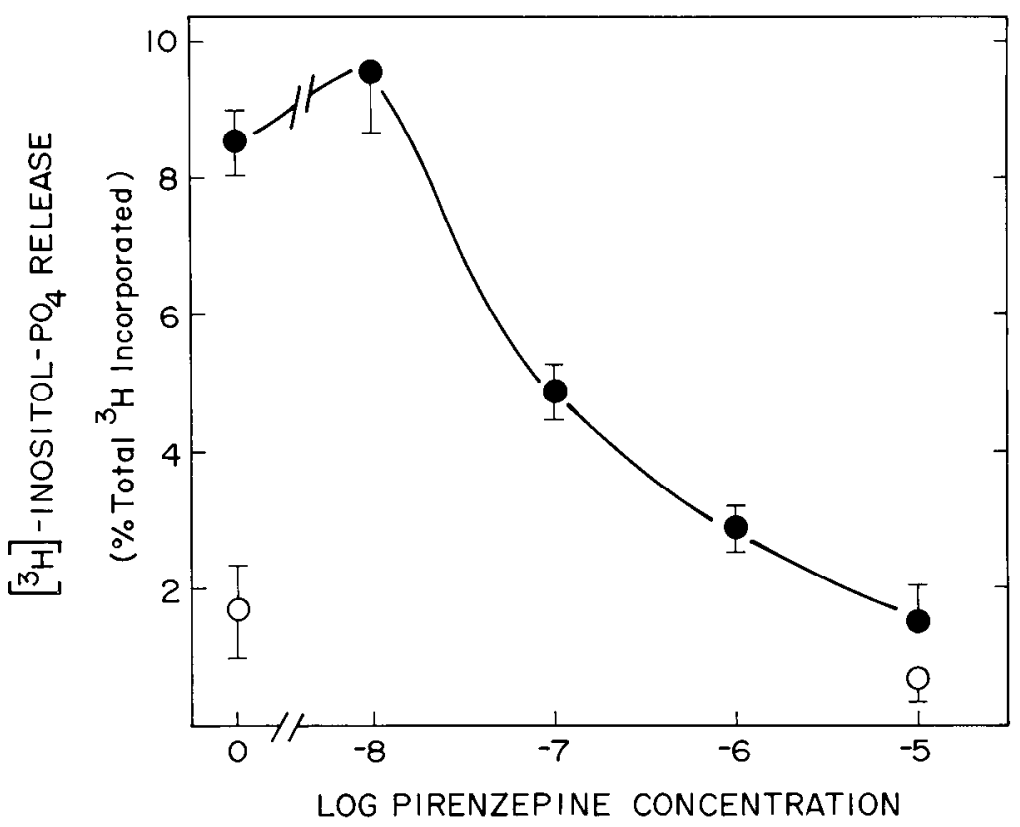

Figure 7. Pirenzepine inhibition of carbachol-stimulated inositide breakdown. Data were obtained as described in the legend to Figure 5 except that carbachol $(100 \mu \mathrm{M})$ was the stimulant. Solid circles indicate carbachol-stimulated release of inositol phosphates in the presence of the indicated concentration of pirenzepine. Open circles show nonstimulated release in the presence or absence of pirenzepine. Data represent means \pm SEM of triplicate incubations done on a single slice preparation. Similar results were obtained in a separate experiment.

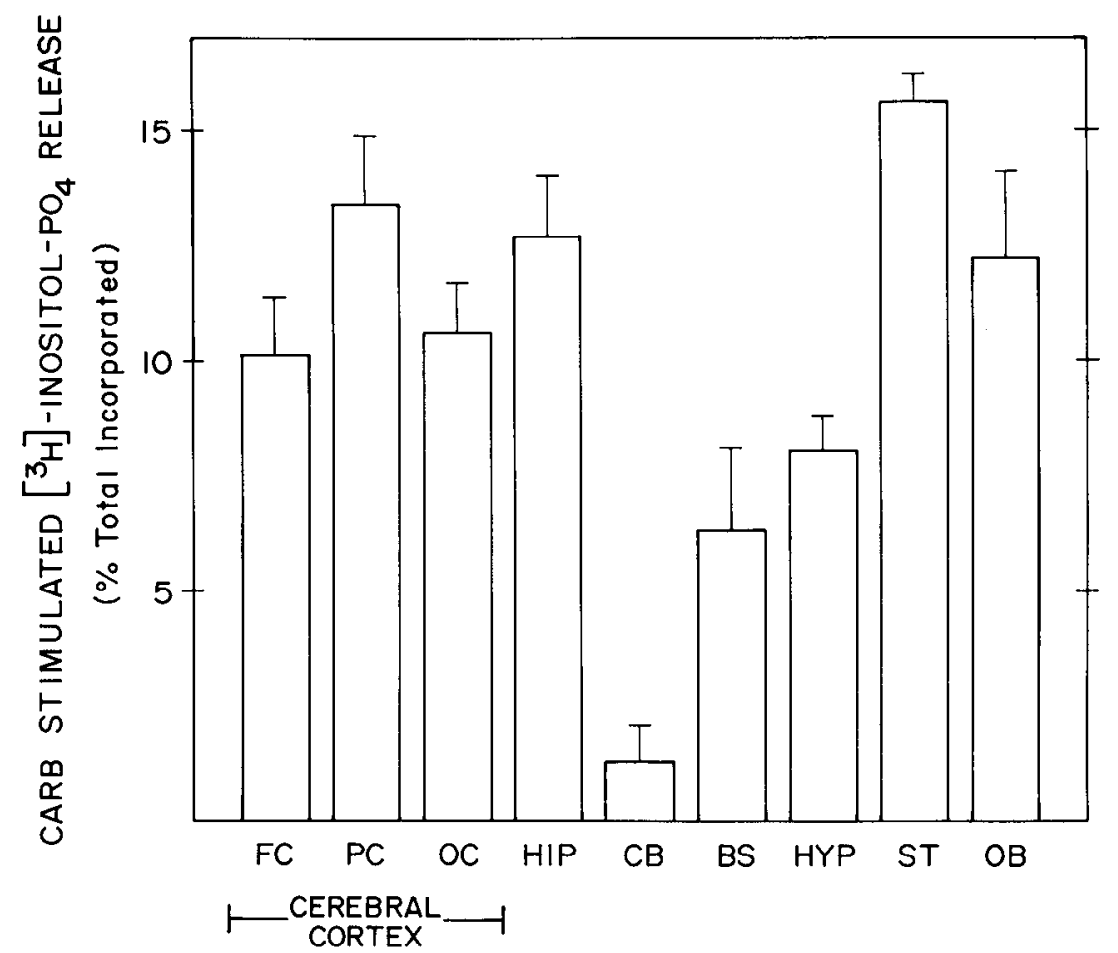

Figure 8. Carbachol-stimulated inositide breakdown in rat brain regions. Data were obtained as described in the legend to Figure 4. Release in the absence of carbachol was subtracted from that in the presence of carbachol $(1 \mathrm{mM})$, and only the net carbachol-stimulated response is shown. Nonstimulated release was similar in all brain regions. Shown are the means \pm SEM of six determinations for two separate experiments except the olfactory bulb and occipital cortex (triplicate determinations on a single preparation). The different regions are labeled as follows: $F C$, frontal cortex; $P C$, parietal cortex; $O C$, occipital cortex, $H I P$, hippocampus; $C B$, cerebellum; $B S$, brainstem; $H Y P$, hypothalamus; $S T$, striatum; $O B$, olfactory bulb.

several peripheral tissues is the stimulation of PI breakdown (Berridge et al., 1982; Brown and Brown, 1983; Putney et al., 1983). We have characterized this response in rat brain slices by following the accumulation of inositol phosphate. During the characterization of this method, we have made modifications to previous methods (Berridge et al., 1982; Berridge, 1983) which allow a more rigorous analysis of the effects of various agents on the breakdown of inositides in brain tissue. In particular, our decision to express our data as percentage of release corrects for variations in the amount of slices incubated in each tube (i.e., protein). This modification allows experiments to be done on the linear portion of the protein curve.

The muscarinic receptor-stimulated accumulation of inositol phosphates could be due to hydrolysis of any or all of the innsitol lipids. Recent studies in other tissues have suggested that the initial receptor-stimulated event is the hydrolysis of the polyphosphoinositides to release inositol polyphosphates which are then rapidly dephosphorylated to inositol 1-phosphatase (Berridge et al., 1983). Due to inhibition of inositol 1phosphatase by lithium (Berridge et al., 1982), inositol 1phosphate accumulates under conditions of receptor activation. Thus, it is not clear which of the inositol lipids is hydrolyzed during muscarinic receptor stimulation in rat brain slices. The differences in efficacy for hydrolysis of inositol lipids by various muscarinic receptor agonists which we obtained in rat brain slices agree well with those of Fisher et al. (1983) using ${ }^{32} \mathrm{P}_{\mathrm{i}}$ incorporation into guinea pig synaptosomal inositol lipids and appear to be related to the ability of agonists to induce conformational changes in the muscarinic receptor which subsequently stimulate the hydrolysis of inositol lipids (Fisher et al., 1984). Thus, muscarinic receptor stimulation in brain appears to involve the rapid hydrolysis and resynthesis of inositol lipids. 
Figure 9. Calcium dependence of carbacholstimulated inositide breakdown. Cortical slices were labeled as described under "Materials and Methods." Slices were washed with KRB without calcium before aliquoting into tubes containing $\mathrm{KRB}$ + lithium + the amount of calcium or EGTA indicated. Carbachol was then added ( $1 \mathrm{mM}$ ) for 60 min. Asterisks indicate significant differences from the carbachol stimulation with no calcium added (analysis of variance followed by Newman-Keuls test, $p<0.05$ ). No significant differences were found for nonstimulated release. Open bars indicate basal release and hatched bars are the release in the presence of carbachol. Shown are the means \pm SEM of triplicate determinations for a single preparation. Separate experiments confirmed that concentrations of EGTA down to $50 \mu \mathrm{M}$ inhibited carbachol-stimulated inositide breakdown.

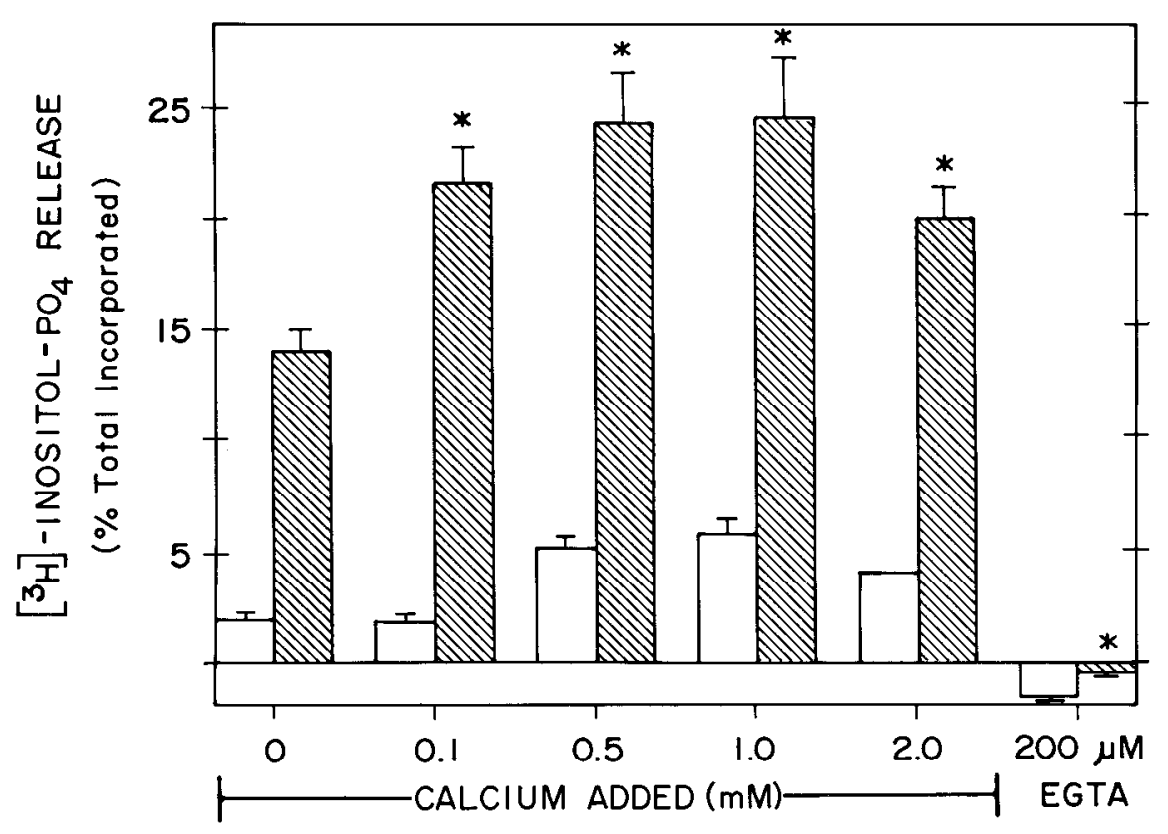

The muscarinic receptor-stimulated breakdown of inositide as shown in this study appears to be calcium sensitive. Other investigators have suggested that the muscarinic receptor stimulation of ${ }^{32} \mathrm{P}_{\mathrm{i}}$ incorporation into $\mathrm{PI}$ in brain is calcium dependent (Griffin et al., 1979; Fisher and Agranoff, 1980). Thus, our results suggest that inositide breakdown may not be associated with calcium mobilization in brain, unlike that found for many peripheral tissues (Kirk et al., 1981; Billah and Lapetina, 1982; Weiss et al., 1982). However, we cannot exclude the possibility that one of the polyphosphoinositides may be preferentially hydrolyzed in a calcium-independent step (Berridge et al., 1983). Results from other tissues suggest that phosphatidylinositol 4-phosphate or phosphatidylinositol 4,5-bisphosphate may be broken down first (Berridge et al., 1983; Putney et al., 1983). The polyphosphoinositides represented only $15 \%$ of the total $\left[{ }^{3} \mathrm{H}\right]$ inositol incorporated into brain slice phosphoinositides. It is possible that the specific calcium-independent breakdown of one of the polyphosphoinositides would not be detected in brain slices.

Inositol lipids have been shown to be hydrolyzed to inositol phosphates and diacylglycerol (DAG) in a number of peripheral tissues (Michell, 1983). DAG formed from thrombin stimulation of inositide breakdown activates a calcium phospholipiddependent protein kinase in platelets causing aggregation and serotonin release (Sano et al., 1983). Calcium phospholipiddependent protein kinase activity is higher in brain than in any other tissue (Kuo et al., 1980) and is likely to be activated by DAG formed from muscarinic receptor stimulation of inositide breakdown. Thus, cholinergic stimulation of inositol lipid hydrolysis is likely to be the first step in an important intraneuronal cascade.

The cholinergic stimulation of inositide breakdown in brain slices is clearly muscarinic. Muscarinic agonists stimulate the response, whereas nicotinic agonists do not (e.g., 1,1-dimethyl4-phenylpiperazinium); muscarinic antagonists block the response (e.g., atropine and scopolamine), and nicotinic antagonists do not alter the response. Although gallamine has been reported to modify muscarinic receptor binding at high concentrations (Stockton et al., 1983), the concentration we used (1 $\mu \mathrm{M})$ would be selective for nicotinic sites. Recent binding studies have suggested that there are muscarinic receptor subtypes (Hammer et al., 1980). One of these muscarinic receptor subtypes is likely to be coupled to inositide hydrolysis. We found large responses in the striatum, cerebral cortex, and hippocam- pus. These findings are consistent with the regional distribution of $\mathrm{M}_{1}$ receptors (Hammer et al., 1980; Watson et al., 1984). In addition, pirenzepine, a selective $\mathbf{M}_{1}$ antagonist (Polter et al., 1984; Watson et al., 1984), blocked carbachol stimulation of inositol phosphate release. However, more data are required to determine definitively the subtype of muscarinic receptor coupled to inositide hydrolysis. Variations in agonist efficacy, selective antagonists, and/or modifiers may be important tools for the characterization of central muscarinic receptor subtypes. Clearly, one type of central muscarinic receptor is coupled to hydrolysis of inositides and this is likely to be the initial step in an intraneuronal cascade including the activation of the calcium phospholipid-dependent protein kinase.

\section{References}

Berridge, M. J., C. P. Downes, and M. R. Hanley (1982) Lithium amplifies agonist-dependent phosphatidylinositol responses in brain and salivary glands. Biochem. J. 206: 587-595.

Berridge, M. J. (1983) Rapid accumulation of inositol triphosphate reveals that agonists hydrolyse polyphosphoinositides instead of phosphatidylinositol. Biochem. J. 212: 849-858.

Berridge, M. J., R. M. C. Dawson, C. P. Downes, J. P. Heslop, and R. F. Irvine (1983) Changes in the levels of inositol phosphates after agonist-dependent hydrolysis of membrane phosphoinositides. Biochem. J. 212: 473-482.

Billah, M. M., and E. G. Lapetina (1982) Rapid decrease of phosphatidylinositol 4,5-bisphosphate in thrombin-stimulated platelets. J. Biol. Chem. 257: 12705-12708.

Brown, S. L., and J. H. Brown (1983) Muscarinic stimulation of phosphatidylinositol metabolism in atria. Mol. Pharmacol. 24: 351356.

Clarke, N. G., and R. M. C. Dawson (1981) Alkaline $O \rightarrow N$-transacylation: A new method for the quantitative deacylation of phospholip ids. Biochem. J. 195: 301-306.

Downes, C. P., and R. H. Michell (1982) Phosphatidylinositol 4 phosphate and phosphatidylinositol 4,5-bisphosphate: Lipids in search of a function. Cell Calcium 3: 467-502.

Farese, R. V. (1983) The phosphatidate-phosphoinositide cycle: An intracellular messenger system in the action of hormones and neurotransmitter. Metabolism 32: 628-641.

Fisher, S. K., and B. W. Agranoff (1980) Calcium and the muscarinic synaptosomal phospholipid labeling effect. J. Neurochem. 34: 12311240.

Fisher, S. K., P. D. Klinger, and B. W. Agranoff (1983) Muscarinic agonist binding and phospholipid turnover in brain. J. Biol. Chem. 258: $7358-7363$.

Fisher, S. K., J. C. Figueiredo, and R. T. Bartus (1984) Differential 
stimulation of inositol phospholipid turnover in brain by analogs of oxotremorine. J. Neurochem., in press.

Goldstein, A. (1964) Correlation. In Biostatistics-An Introductory Text, pp. 129-187, MacMillan Co., New York.

Griffin, H. W., J. N. Hawthorne, and M. Sykes (1979) A calcium requirement for the phosphatidylinositol response following activation of presynaptic muscarinic receptors. Biochem. Pharmacol. 28. $1143-1147$.

Hammer, R., C. P. Berrie, N. J. M. Birdsall, A. S. V. Burgen, and E. C. Hulme (1980) Pirenzepine distinguishes between different subclasses of muscarinic receptors. Nature 283: 90-92.

Kirk, C. J., J. A. Creba, C. P. Downes, and R. H. Michell (1981) Hormone-stimulated metabolism of inositol lipids and its relationship to hepatic receptor function. Biochem. Soc. Trans. 9: 377-379.

Krnjevic, K. (1974) Chemical nature of synaptic transmission in vertebrates. Physiol. Rev. 54: 418-540.

Kuo, J. F., R. G. G. Andersson, B. C. Wise, L. Mackerlova, I. Salomonsson, N. C. Brackett, N. Katoh, M. Shoji, and R. W. Wrenn (1980) Calcium-dependent protein-kinase: Widespread occurrence in various tissues and phyla of the animal kingdom and comparison of effects of phospholipid, calmodulin, and trifluoperazine. Proc. Natl. Acad. Sci. U. S. A. 77: 7039-7043.

Lowry, O. H., N. J. Rosebrough, A. L. Farr, and R. J. Randall (1951) Protein measurement with the Folin phenol reagent. J. Biol. Chem. 192: $265-275$

Michell, R. H. (1975) Inositol phospholipids and cell surface receptor function. Biochem. Biophys. Acta 415: 81-147.

Michell, B. (1983) $\mathrm{Ca}^{2+}$ and protein kinase C: Two synergistic cellular signals. Trends Biochem. Sci. 8: 263-265.
Paxinos, G., and C. Watson (1982) The Rat Brain in Stereotaxic Coordinates, Academic Press, Inc., New York.

Potter, L. T., D. D. Flynn, H. E. Hanchett, D. L. Kalinoski, J. LuberNarod, and D. C. Mash (1984) Independent $\mathrm{M}_{1}$ and $\mathrm{M}_{2}$ receptors: Ligands, autoradiography and functions. Trends Pharmacol. Sci. Suppl. 7: 22-31.

Putney, J. W., Jr., G. M. Burgess, S. P. Halenda, J. S. McKinney, and R. P. Rubin (1983) Effects of secretagogues on $\left.{ }^{32} \mathrm{P}\right]$ phosphatidylinositol 4,5-bisphosphate metabolism in the exocrine pancreas. Biochem. J. 212: 483-488.

Rouser, G., S. Fleischer, and A. Yamamoto (1969) Two dimensional thin layer chromatographic separation of polar lipid and determination of phospholipids by phosphorus analysis of spots. Lipids 5: 494496.

Sano, K., Y. Takai, J. Yamanishi, and Y. Nishizuka (1983) A role of calcium-activated phospholipid-dependent protein kinase in human platelet activation. J. Biol. Chem. 258: 2010-2013.

Sherman, W. R., A. L. Leavitt, M. P. Honchar, L. M. Hallcher, and B. E. Phillips (1981) Evidence that lithium alters phosphoinositide metabolism: Chronic administration elevates primarily D-myo-inositol-1-phosphate in cerebral cortex of the rat. J. Neurochem. 36 $1947-1951$.

Stockton, J. M., N. J. M. Birdsall, A. S. V. Burgen, and E. C. Hulme (1983) Modification of the binding properties of muscarinic receptors by gallamine. Mol. Pharmacol. 23: 551-557.

Watson, M., T. W. Vickroy, W. R. Roeske, and H. I. Yamamura (1984) Subclassification of muscarinic receptors based upon the selective antagonist pirenzepine. Trends Pharmacol. Sci. Suppl. 7: 9-11.

Weiss, S. J., J. S. McKinney, and J. W. Putney, Jr. (1982) Receptormediated net breakdown of phosphatidylinositol 4,5-bisphosphate in parotid acinar cells. Biochem. J. 206: 555-560. 